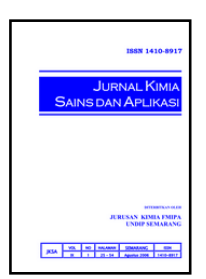

\title{
Aktivitas Inhibisi $\alpha$-Glukosidase dan Identifikasi Senyawa dalam Fraksi Aktif Bunga Rosella (Hibiscus Sabdariffa L.)
}

\author{
Irma Yunitasari ${ }^{\text {a }}$, Agustina L. N. Aminin ${ }^{\text {a }}$, Khairul Anam ${ }^{\text {a }}$ \\ a Chemistry Department, Faculty of Sciences and Mathematics, Diponegoro University, Jalan Prof. Soedarto, Tembalang, Semarang \\ * Corresponding author: k.anam@live.undip.ac.id
}

\begin{tabular}{l} 
Article Info \\
\hline Keywords: \\
$\alpha$-glukosidase \\
inhibitors, rosella \\
(Hibiscus sabdariffa \\
L), flavonoid
\end{tabular}

Kata Kunci:

Inhibisi $\alpha-$

glukosidase, rosella

(Hibiscus sabdariffa

$L)$, flavonoid

\begin{abstract}
Roselle is a plant that can be used to combat disease diabetes mellitus (DM), the DM in therapy can be done by inhibiting the $\alpha$-glucosidase enzyme work. This research aims to get active fraction of the extract of the flower as a potential $\alpha$ glucosidase inhibitor and identify the types of compounds in the active fraction. The methods used in this research is the use of extraction solvents methanol- $\mathrm{HCl} 0.1 \%$, followed by oil chromatography stationary phase column with sephadex LH-20 motion and phase water-methanol fraction A (100:0), fraction B (75:25), the fraction C (50:50), fraction D (25:75), fraction E (0:100), and test activity inhibition of $\alpha$-glucosidase rosella flower faction. The identification of active compounds which has the highest value inhibitory activities of $\alpha$-glucosidase use TLC and patches appearence ( $\mathrm{AlCl}_{3}, \mathrm{FeCl}_{3}$ and ammonia vapours), the determination of the levels of relative (\%) a component of the active fraction with TLC scanner, and characterization of the main compound in the active fraction using UV-Vis spectrophotometer and FTIR. Research showed that faction C (50:50) is a active fraction which assigns grades activity inhibition $\alpha$-glukosidase highest $(31,163 \%)$ at concentrations $1000 \mathrm{ppm}$, and compound main in faction $\mathrm{C}$ is $3,3^{\prime}, 4^{\prime}$-trihydroksiflavone and 5,7,3',4'-tetrahydroksiflavone with each levels relatively $23,33 \%$ and $24,52 \%$.
\end{abstract}

\section{Abstrak}

Rosela merupakan tanaman yang dapat digunakan untuk mengatasi penyakit diabetes melitus (DM), dalam terapi DM dapat dilakukan dengan menghambat kerja enzim $\alpha-$ glukosidase. Penelitian ini bertujuan untuk mendapatkan fraksi aktif dari ekstrak bunga rosella yang berpotensi sebagai inhibitor $\alpha$-glukosidase dan mengidentifikasi jenis senyawa dalam fraksi aktif tersebut. Metode yang digunakan pada penelitian ini adalah ekstraksi menggunakan pelarut metanol- $\mathrm{HCl} 0,1 \%$, dilanjutkan fraksinasi secara kromatografi kolom dengan fasa diam sephadex LH-20 dan fasa gerak air-metanol fraksi A (100:0), fraksi B (75:25), fraksi C (50:50), fraksi D (25:75), fraksi E (0:100), dan uji aktivitas inhibisi $\alpha$-glukosidase fraksi bunga rosella. Identifikasi senyawa aktif yang memberikan nilai aktivitas penghambatan $\alpha$-glukosidase paling tinggi dengan KLT dan penampak bercak $\left(\mathrm{AlCl}_{3}\right.$, uap amoniak dan $\left.\mathrm{FeCl}_{3}\right)$, penentuan kadar relatif (\%) komponen dari fraksi aktif dengan TLC scanner, dan karakterisasi senyawa utama dalam fraksi aktif menggunakan spektrofotometer UV-Vis dan FTIR. Hasil penelitian menunjukan bahwa fraksi C (50:50) merupakan fraksi aktif yang memberikan nilai aktivitas inhibisi $\alpha-$ glukosidase paling tinggi $(31,163 \%)$ pada konsentrasi $1000 \mathrm{ppm}$, dan senyawa utama dalam fraksi C adalah 3,3',4' -trihidroksiflavon dan 5,7,3',4' -tetrahidroksiflavon dengan masing-masing kadar relatif $23,33 \%$ dan $24,52 \%$. 


\section{Pendahuluan}

Diabetes Melitus (DM) adalah kondisi konsentrasi glukosa dalam darah secara kronis lebih tinggi daripada nilai normal (hiperglikemia) akibat tubuh kekurangan insulin atau fungsi insulin tidak efektif. Meningkatnya jumlah penderita diabetes melitus setiap tahunnya menuntut perhatian serius dalam terapi penyakit tersebut. Terapi dengan obat-obat sintetis sering memberi efek samping dan biaya tinggi akibat pengobatan jangka panjang. Obat tradisional merupakan salah satu alternatif dalam pengobatan, karena efek sampingnya yang dianggap lebih kecil dan biaya yang lebih murah [1,2].

Salah satu metode pengobatan penyakit diabetes melitus adalah dengan menghambat aktivitas enzim $\alpha-$ glukosidase dengan suatu senyawa inhibitor $\alpha$ glukosidase. Senyawa ini mampu mengurangi peningkatan kadar glukosa darah pada penderita diabetes. Senyawa dari fitokimia tanaman termasuk polifenol memiliki aktivitas dalam menghambat aktivitas enzim $\alpha$-glukosidase [3].

Rosella (Hibiscus sabdariffa L.) merupakan salah satu jenis tanaman obat yang secara tradisional digunakan sebagai obat antidiabetes [4]. Kandungan kimia yang terdapat dalam kelopak bunga rosella adalah saponin, tanin dan flavonoid yang terdiri dari flavonol dan antosianin [5]. Penelitian mengenai kelopak bunga rosella sebagai obat antidiabetes diantaranya dilaporkan oleh Urifah [6] bahwa ekstrak air kelopak bunga rosella memiliki aktivitas penghambatan enzim $\alpha$-glukosidase sebesar 82,6-93,5 \%. Ademiluyi dan Oboh [7] membandingkan ekstrak air bunga rosella merah memilki aktivitas antidiabetes lebih besar (IC $_{50} 25,2$ $\mu \mathrm{g} / \mathrm{ml}$ ) jika dibandingkan dengan bunga rosella putih. Widarsa dan Wiranatha [8] juga melaporkan ekstrak bunga rosella dapat menurunkan kadar glukosa darah mencit diabetes, diperkuat oleh penelitian Setiawan [9] yang menyatakan bahwa ekstrak bunga rosella juga dapat menurunkan kadar gula darah tikus putih. Penelitian-penelitian tersebut telah memberikan bukti bahwa ekstrak kelopak bunga rosella dapat berfungsi sebagai obat antidiabetes.

Penelitian terdahulu umumnya hanya melaporkan aktivitas dari ekstrak bunga rosella dalam menginhibisi aktivitas enzim $\alpha$-glukosidase, namun sampai saat ini belum pernah dilaporkan mengenai aktivitas dari fraksi-fraksinya. Sehingga pada penelitian ini dilakukan uji aktivitas inhibisi $\alpha$-glukosidase dari masing-masing fraksi dan diidentifikasi kandungan kimia yang terdapat dalam fraksi aktif.

\section{Metode Penelitian}

\section{Alat dan Bahan}

Alat yang digunakan antara lain peralatan gelas, chamber, pipet kapiler, vial, neraca analitik (Kern-870), rotary vacuum evaporator (Buchii b-480), plat tetes, penangas, kolom kromatografi, hairdrayer, microplate, multipipet, pipet mohr, bulb, lampu UV, freezedryer (Eyela), TLC Scanner (Camag TLC Scanner 3), spektrofotometer UV-Vis (T60 U Spectrometer PG Instrument) dan FTIR (FTIR spectrophotometer 8201PC Shimadzu). Kelopak bunga rosella, metanol, natrium hidroksida, natrium asetat, asam borat, alumunium klorida, $\mathrm{HCl} 2 \mathrm{~N}$, amoniak 25\%, kloroform, etil asetat, etanol, n-Heksana, pereaksi Dragendorff, pereaksi Meyer, serbuk magnesium, besi(III) klorida, anhidrida asam asetat, amil alkohol, eter, asam sulfat pekat, akuades, $p$-nitrofenil- $\alpha-\mathrm{D}$-glukopiranosida, buffer posfat $\mathrm{pH} 7.0$, enzim $\alpha$-glukosidase, larutan natrium karbonat, glukobay, Silika Gel 60HF 254 , sephadex LH-20.

\section{Preparasi dan Ekstraksi sampel}

Kelopak bunga rosella (Hibiscus sabdariffa.) diperoleh dari perkebunan Wonosobo, Jawa tengah, Indonesia. Kelopak rosella (Hibiscus sabdariffa.) dibersihkan dari biji, kemudian di potong-potong sehingga di dapatkan kelopak bunga rosella dengan ukuran yang lebih kecil.

Sebanyak 1,5 kg simplisia dimaserasi menggunakan 4,5 L campuran pelarut metanol dengan 4,5 ml HCl (1000:1). Maserasi dilakukan dengan perendaman simplisia selama 3×24 jam. Filtrat yang diperoleh dipekatkan menggunakan rotary vacuum evaporator pada suhu $60^{\circ} \mathrm{C}$. Ekstrak kental rosella yang diperoleh disimpan pada suhu $4^{\circ} \mathrm{C}$ untuk digunakan pada tahap selanjutnya.

\section{Penapisan Fitokimia}

Penapisan fitokimia dilakukan pada ekstrak pekat Rosela (Hibiscus sabdariffa L.). Senyawa yang diidentifikasi adalah senyawa golongan alkaloid, flavonoid, saponin, tanin dan triterpenoid/steroid dan antosianin menggunakan metode yang dikembangkan oleh Farnsworth [10].

\section{Fraksinasi Ekstrak Metanol-HCl Bunga Rosella.}

Sebanyak 2 gram ekstrak metanol-HCl bunga rosella difraksinasi menggunakan kromatografi kolom dengan fasa diam sephadex LH-20 dan fasa gerak air:metanol berturut-turut dengan perbandingan fraksi A (100:0), fraksi B (75:25), fraksi C (50:50), fraksi D (25:75) dan fraksi E (0:100). Fraksinasi dilakukan dengan menggunakan $1 \mathrm{~L}$ pelarut sebagai fasa gerak. Hasil fraksi diuapkan menggunakan rotary evaporator untuk menghilangkan pelarut metanol dan dihilangkan sisa pelarut airnya dengan menggunakan metode freeze-dryer. Fraksinasi dilakukan 10 kali pengulangan untuk memperbanyak hasil fraksi.

Uji Aktivitas Inhibisi $\alpha$-glukosidase dari Fraksi dan Ekstrak Bunga Rosella (Sancheti dkk., 2009).

\section{Preparasi sampel}

Sampel yang diuji dilarutkan dalam pelarut dimetil sulfoksida (DMSO) dengan konsentrasi $1 \%$ (b/v).

Uji in vitro ekstrak dan fraksi bunga rosela terhadap aktivitas $\alpha$-glukosidase.

Setiap sampel dibuat larutan induk $1000 \mathrm{ppm}$. Setiap sampel diencerkan menjadi 500 ppm. Setiap konsentrasi sampel dipipet sebanyak $10 \mu \mathrm{L}$ kedalam 
microplate ditambahkan $25 \mu \mathrm{L}$ substrat ( $p$-nitrophenil$\alpha$-D-glucopyranoside), $50 \mu \mathrm{L}$ buffer posfat $\mathrm{pH}$ 7.0, dan $25 \mu \mathrm{L}$ enzim $\alpha$-glukosidase. Kemudian diinkubasi selama 30 menit pada suhu $37^{\circ} \mathrm{C}$. Reaksi enzim dihentikan dengan penambahan $100 \mu \mathrm{L}$ natrium karbonat dan dibaca absorbannya pada panjang gelombang $410 \mathrm{~nm}$. Larutan standar (glukobay) dibuat dengan konsenterasi $1 \mathrm{ppm}, 0,5 \mathrm{ppm}, 0,1 \mathrm{ppm}, 0,01 \mathrm{ppm}$ dan 0,001. Persen inhibisi dapat dihitung dari persamaan :

$$
\% \text { Inhibisi }=\frac{(\mathrm{C}-\mathrm{S})}{\mathrm{C}} \times 100 \%
$$

Keterangan:

\section{$\mathrm{S}=$ Absorbansi sampel}

\section{$\mathrm{C}=$ Absorbansi blanko}

\section{Identifikasi Komponen Kimia Fraksi Aktif}

Fraksi paling aktif, diidentifikasi komponen penyusunnya menggunakan metode kromatografi lapis tipis (KLT), pemisahan dilakukan secara kromatografi lapis tipis dengan eluen etanol:kloroform (4:1). Dari hasil KLT noda dilakukan uji penampak bercak $\mathrm{AlCl}_{3} 5 \%$ (dalam etanol), $\mathrm{FeCl}_{3}$ dan $\mathrm{NH}_{3}$, dan noda yang paling dominan dari fraksi aktif dikerok dan dilarutkan dalam metanol p.a.

\section{Penentuan Kadar Komponen Penyusun Fraksi Aktif} dan Uji Kemurnian

Kromatografi lapis tipis dengan menggunakan eluen etanol:kloroform (4:1) selanjutnya dilakukan pengujian terhadap kadar relatif area noda (\%) dengan menggunakan TLC Scanner $(\lambda: 365 \mathrm{~nm})$. KLT preparatif dilakukan untuk noda yang memiliki kadar relatif (\%) paling besar. Isolat yang diperoleh dilakukan uji kemurnian dengan menggunakan kromatografi lapis tipis dengan berbagai pengembang.

\section{Karakterisasi Isolat Murni}

Isolat murni yang didapat dikarakterisasi dengan menggunakan spektrofotometer $U V$-Vis dengan penambahan pereaksi geser: $\mathrm{NaOH} 2 \mathrm{M}, \mathrm{AlCl}_{3}, \mathrm{AlCl}_{3} / \mathrm{HCl}$, $\mathrm{NaOAC}, \mathrm{NaOAC} / \mathrm{H}_{3} \mathrm{BO}_{3}$ [11] dan Spektrofotometer FTIR.

\section{Hasil dan Pembahasan}

\section{Ekstraksi Bunga rosella}

Pembuatan ekstrak bunga rosella dilakukan dengan metode maserasi menggunakan pelarut metanol-HCl 0,1\%. Pemilihan pelarut ini karena metanol mempunyai sifat polar, dimana flavonoid bersifat polar sehingga akan mudah larut dalam pelarut yang bersifat polar. Penambahan $\mathrm{HCl}$ sebanyak $0,1 \%$ dalam metanol untuk mengkondisikan pelarut dalam suasana asam. Hal ini bertujuan agar diperoleh senyawa dalam bentuk aglikonnya [12] dan senyawa yang diisolasi merupakan senyawa yang larut atau stabil dalam suasana asam kuat. Maserasi dilakukan sampai warna kulit dari kelopak bunga rosella yang semula berwarna merah menjadi pudar. Filtrat hasil maserasi dipekatkan dengan rotary vacuum evaporator sehingga diperoleh ekstrak kental berwarna merah tua dengan rendemen sebesar 4,07\%.

\section{Penapisan Fitokimia Ekstrak Rosella}

Penapisan fitokimia terhadap kelopak bunga rosella (Hibisdicus sabdariffa L.) bertujuan untuk mengetahui jenis senyawa metabolit sekunder pada kelopak bunga rosella. Golongan kimia yang diidentifikasi pada penelitian ini antara lain alkaloid, flavonoid, antosianin, triterpenoid/steroid dan saponin. Hasil dari penapisan fitokimia tertera pada Tabel 1.

Tabel 1: Hasil penapisan fitokimia ekstrak rosella (Hibiscus sabdariffa L.)

\begin{tabular}{cc}
\hline Senyawa Metabolit Sekunder & Hasil Uji $(+) /(-)$ \\
\hline Flavonoid & + \\
Antosianin & + \\
Alkaloid & - \\
Triterpenoid dan Steroid & - \\
Saponin & + \\
Tanin & + \\
\hline
\end{tabular}

Hasil penapisan fitokimia menunjukan ekstrak Metanol-HCl 0,1 \% positif terhadap senyawa flavonoid, antosianin, tanin, dan saponin, serta negatif untuk uji alkaloid, triterpenoid dan steroid. Hasil penelitian ini sesuai dengan laporan yang menyatakan bahwa penapisan fitokimia ekstrak tanaman rosella (Hisbiscus sabdarifa L.) mengandung flavonoid, saponin dan tanin [13].

\section{Fraksinasi Ekstrak Bunga Rosella}

Fraksinasi dilakukan terhadap ekstrak bunga rosella secara kromatografi kolom gravitasi. Fase diam yang digunakan adalah sephadex LH-20 dan fase gerak air:metanol (100:0; 75:25; 50;50; 25:75; 0:100). Pemisahan menggunakan fase diam sephadex LH-20 adalah pemisahan berdasarkan ukuran partikel [14]. Urutan elusi yang dilakukan pada penelitian diharapkan dapat memisahkan dari senyawa yang ukurannya besar ke senyawa yang lebih kecil. Kromatografi kolom sephadex ini sangat efektif untuk memisahkan golongan glikosida dan senyawa yang berat molekul besar [15]. Fraksi yang diperoleh sebanyak 5 jenis (fraksi A,B,C,D dan E) dengan intensitas warna yang berbeda setiap fraksinya. Hal ini menandakan bahwa fraksi memiliki kandungan kimia yang berbeda. Eluat yang dihasilkan diuapkan pelarut metanolnya menggunakan rotary vacuum evaporator. Setelah bebas dari metanol kemudian dilakukan freeze drying untuk menghilangkan pelarut airnya.

Tabel 2: Hasil berat dari freeze drying

\begin{tabular}{cc}
\hline $\begin{array}{c}\text { Sampel fraksinasi } \\
\text { (air:metanol) }\end{array}$ & $\begin{array}{c}\text { Berat hasil freeze } \\
\text { drying (gr) }\end{array}$ \\
\hline A (100:0) & 15,5358 \\
B (75:25) & 0,12 \\
C (50:50) & 0,06 \\
D (25:75) & 0,0167 \\
E (0:100) & Tidak diperoleh \\
\hline
\end{tabular}


Sampel yang diperoleh berbentuk serbuk, hal ini agar dapat di hitung massanya untuk dilakukan pengujian terhadap aktivitas inhibisi $\alpha$-glukosidase. Pengujian aktivitas inhibisi $\alpha$-glukosidase dilakukan pada fraksi A, B, dan C. Fraksi D dan E tidak memungkinkan dilakukan uji karena berat massa yang diperoleh sangat sedikit.

\section{Uji Aktivitas Inhibisi $\alpha$-glukosidase}

Pada penelitian ini uji aktivitas inhibisi $\alpha-$ glukosidase dilakukan untuk mengetahui persen hambat enzim $\alpha$-glukosidase dari setiap fraksi dan ekstrak bunga rosella. Pengujian aktivitas inhibisi dilakukan secara in vitro dengan menggunakan substrat $p$-nitrofenil- $\alpha$-D-glukopiranosida ( $p$-NPG) dan enzim $\alpha$-glukosidase. Aktivitas enzim diukur berdasarkan hasil absorbansi p-nitrofenol yang berwarna kuning, semakin berkurangnya intensitas warna kuning maka semakin besar aktivitas inhibisi dari suatu sampel.

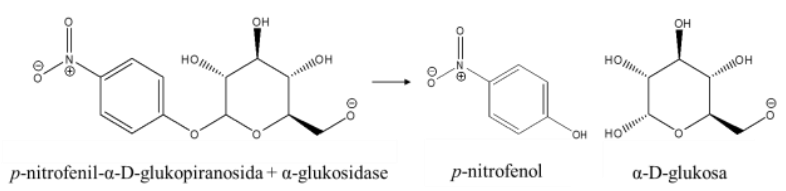

Gambar 1. Persamaan reaksi enzimatik $\alpha$-glukosidase dan $\mathrm{p}$-nitrofenil- $\alpha-\mathrm{D}$ glukopiranosida [16]

Pengujian aktivitas inhibisi $\alpha$-glukosidase dari ekstrak dan ketiga fraksi memberikan hasil yang beragam, hal tersebut dapat terjadi karena kandungan masing-masing senyawa dalam fraksi berbeda. Hasil pengujian aktivitas inhibisi $\alpha$-glukosidase adalah:

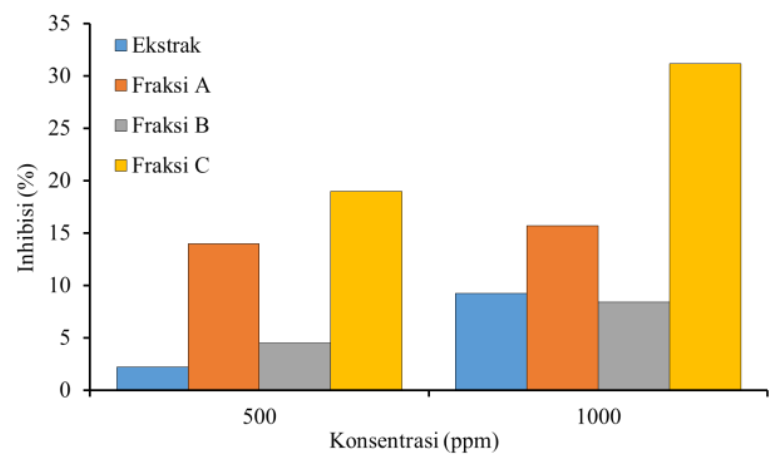

Gambar 2. Grafik hasil uji kemampuan inhibisi ekstrak dan fraksi (A, B, C).

Pengujian dilakukan pada konsentrasi 500 ppm, dan $1000 \mathrm{ppm}$, hal ini bertujuan untuk melihat pengaruh konsentrasi terhadap daya hambat dari masing-masing fraksi. Besarnya nilai inhibisi dipengaruhi oleh tingginya konsentrasi senyawa inhibitor. Semakin tinggi konsentrasi senyawa inhibitor akan semakin besar pula kemampuan inhibisinya. Hasil yang diperoleh, fraksi C memiliki aktivitas paling besar yaitu pada konsentrasi 1000 ppm dapat menghambat sebesar $31,163 \%$. Hal tersebut diduga karena pengaruh dari komponen kimia yang terdapat pada fraksi aktif memiliki efek sinergis dalam menghambat enzim $\alpha-$ glukosidase [17].
Glukobay merupakan obat yang digunakan untuk menghambat kerja enzim yang memecah karbohidrat menjadi glukosa. Glukobay pada konsentrasi 10 ppm dapat menghambat kerja enzim sebesar $91 \%$. Perbedaan kemampuan inhibisi dari glukobay dan fraksi C disebabkan karena glukobay mengandung senyawa murni akarbosa yang terbukti dapat menginhibisi $\alpha-$ glukosidase melalui mekanisme inhbitor kompetitif, sedangkan fraksi C merupakan hasil fraksinasi dari ekstrak yang masih berupa senyawa campuran sehingga kemampuan inhibisinya kurang optimal.

\section{Identifikasi Kandungan Kimia}

Identifikasi kandungan kimia dilakukan pada fraksi $\mathrm{C}$ yang merupakan fraksi yang memiliki nilai inhibisi paling besar. Identifikasi senyawa dilakukan dengan pemisahan menggunakan KLT dengan pengembang yang digunakan adalah etanol:kloroform (4:1) menghasilkan dua spot noda dengan nilai Rf 0,69 dan $\mathrm{Rf}$ 0,76 spot yang terbentuk dideteksi dengan sinar UV pada panjang gelombang $254 \mathrm{~nm}$ dan $365 \mathrm{~nm}$. Hasil noda KLT pada Rf 0,69 dan 0,76 pada lampu UV $254 \mathrm{~nm}$ berwarna ungu muda, sedangkan pada UV $365 \mathrm{~nm}$ Rf 0,69 berwarna biru muda dan Rf 0,76 berwarna biru kehijauan.

Identifikasi golongan flavonoid dilakukan dengan senyawa pembanding quersetin yang merupakan jenis flavonoid yang paling sering dijumpai pada pemeriksaan flavonoid [18], penampak bercak dengan $\mathrm{AlCl}_{3} 5 \%$ dalam etanol terjadi perubahan warna menjadi kuning pada lampu UV $365 \mathrm{~nm}$ dan dengan uap amoniak terjadi perubahan menjadi biru berflouresensi. Perubahan ini menandakan kedua noda yang terdapat pada fraksi $\mathrm{C}$ merupakan senyawa golongan flavonoid [18].

Identifikasi senyawa golongan tanin dilakukan dengan menggunakan penampak bercak $\mathrm{FeCl}_{3}$. Senyawa pembanding yang digunakan adalah ekstrak teh yang mengandung senyawa tanin. Hasil yang diperoleh pada kromatogram tidak menunjukan warna hijau kelabu pada fraksi $\mathrm{C}$, namun pada kromatogram pembanding menunjukan warna hijau kelabu pada lampu UV $254 \mathrm{~nm}$. Hal ini menunjukkan bahwa dalam fraksi C tidak mengandung senyawa golongan tanin [18].

\section{Penentuan Kadar Relatif Komponen Penyusun Fraksi} C

Identifikasi dengan menggunakan TLC Scanner adalah untuk mengetahui kadar relatif (\%) komponen area dari setiap noda. Hasil TLC Scanner didapatkan 7 noda yang terdeteksi pada lampu UV $365 \mathrm{~nm}$ yang terdapat pada Tabel 3.

Tabel 3: Hasil TLC Scanner fraksi C dengan panjang gelombang $365 \mathrm{~nm}$.

\begin{tabular}{cccc}
\hline No & Rf & Luas area & Kadar Relatif Area (\%) \\
\hline 1. & 0,41 & 704,4 & 6,54 \\
2. & 0,45 & 1217,6 & 11,30 \\
3. & 0,56 & 821,6 & 7,62 \\
4. & 0,69 & 2513,8 & 23,33 \\
5. & 0,76 & 2642,6 & 24,52 \\
6. & 0,81 & 1986,0 & 18,43 \\
7. & 0,91 & 891,3 & 8,27 \\
\hline
\end{tabular}


Hasil dari TLC Scanner kadar relatif (\%) pada Rf 0,69 dan Rf 0,76 memberikan kadar relatif (\%) area terbesar, sehingga dilakukan KLT preparatif pada noda tersebut. Hasil KLT preparatif selanjutnya dilarutkan dalam pelarut metanol dan diperoleh isolat A (Rf 0,69$)$ dan Isolat $\mathrm{B}(\mathrm{Rf} 0,76)$. Uji kemurnian dilakukan dengan menggunakan berbagai macam pelarut diantaranya etanol:etil asetat (7:3), metanol:kloroform (2:1), etanol:aseton (3:1) dan metanol:n-hexana (5:1). Isolat A dan isolat $B$ menunjukan adanya noda tunggal pada sinar UV $365 \mathrm{~nm}$ dengan demikian dapat dianggap bahwa kedua isolat merupakan senyawa murni.

\section{Karakterisasi Isolat dalam Fraksi C}

Isolat A dan Isolat $\mathrm{B}$ dikarakterisasi menggunakan spektrofotometer UV-Vis dengan pereaksi geser dan FTIR. Penambahan pereaksi geser bertujuan untuk mengetahui letak gugus hidroksi bebas pada inti senyawa flavonoid dengan cara mengamati pergeseran puncak serapan yang terjadi [11].

\section{Karakterisasi isolat A $(\mathrm{Rf} 0,69)$}

Berdasarkan data spektrofotometer UV-Vis isolat A memiliki dua pita serapan yaitu pada $380 \mathrm{~nm}$ (pita I) dan 250 (Pita II). Menurut Markham [11] senyawa yang memiliki pola pita tersebut digolongkan sebagai senyawa flavonol 3-OH bebas. Pergeseran yang terjadi dan penafsirannya ditunjukan pada Tabel 4 .

Tabel 4: Penafsiran pereaksi geser isolat A

\begin{tabular}{|c|c|c|c|c|c|}
\hline \multirow{2}{*}{ Pelarut } & \multicolumn{2}{|c|}{$\lambda_{\max }(\mathrm{nm})$} & \multicolumn{2}{|c|}{$\begin{array}{l}\text { Pergeseran } \\
\quad(\mathrm{nm})\end{array}$} & \multirow{2}{*}{ Penafsiran } \\
\hline & $\begin{array}{l}\text { Pita } \\
\text { I }\end{array}$ & $\begin{array}{l}\text { Pita } \\
\text { II }\end{array}$ & $\begin{array}{l}\text { Pita } \\
\text { I }\end{array}$ & $\begin{array}{l}\text { Pita } \\
\text { II }\end{array}$ & \\
\hline $\mathrm{MeOH}$ & 380 & 250 & - & & \\
\hline $\mathrm{NaOH}$ & 401 & - & 21 & - & $3,4^{\prime} \mathrm{OH}$ \\
\hline $\mathrm{NaOH} 5^{\prime}$ & 392 & 249 & 9 & 1 & \\
\hline NaOAC & 382 & 285 & 2 & 35 & $\begin{array}{l}\text { o-dihidroksi } \\
\text { pada cincin } \mathrm{B}\end{array}$ \\
\hline $\mathrm{NaOAC} / \mathrm{H}_{3} \mathrm{BO}_{3}$ & 392 & - & 12 & - & \\
\hline $\mathrm{AlCl}_{3}$ & 361 & 250 & 19 & - & \\
\hline $\mathrm{AlCl}_{3} / \mathrm{HCl}$ & 359 & 249 & 2 & 1 & $\begin{array}{l}\text { Tidak ada } \\
\text { gugus } 5-\mathrm{OH}\end{array}$ \\
\hline
\end{tabular}

Berdasarkan data hasil analisis spektrofotometer $U V$-Vis dengan menggunakan pereaksi geser diduga senyawa flavonoid dari isolat A adalah 3,3',4'trihidroksiflavon. Karakterisasi selanjutnya menggunakan FTIR, isolat A menunjukan gugus - $\mathrm{OH}$ $\left(3410,15 \mathrm{~cm}^{-1}\right), \mathrm{C}-\mathrm{H}$ alifatik $\left(2947,23 \mathrm{~cm}^{-1} ; 2839,22 \mathrm{~cm}^{-}\right.$ $\left.{ }^{1}\right), \mathrm{C}=\mathrm{O}\left(1651,07 \mathrm{~cm}^{-1}\right), \mathrm{C}=\mathrm{C}\left(1458,18 \mathrm{~cm}^{-1}\right), \mathrm{C}-\mathrm{H}$ tekuk $\left(1419,61 \mathrm{~cm}^{-1}\right), \mathrm{C}-\mathrm{O}-\mathrm{C}\left(111,00 \mathrm{~cm}^{-1}\right), \mathrm{C}-\mathrm{O}\left(1026,13 \mathrm{~cm}^{-1}\right)$, dan benzen tersubstitusi $\left(671,23 \mathrm{~cm}^{-1}\right)$. Spektra FTIR isolat A ditunjukan pada gambar 3.

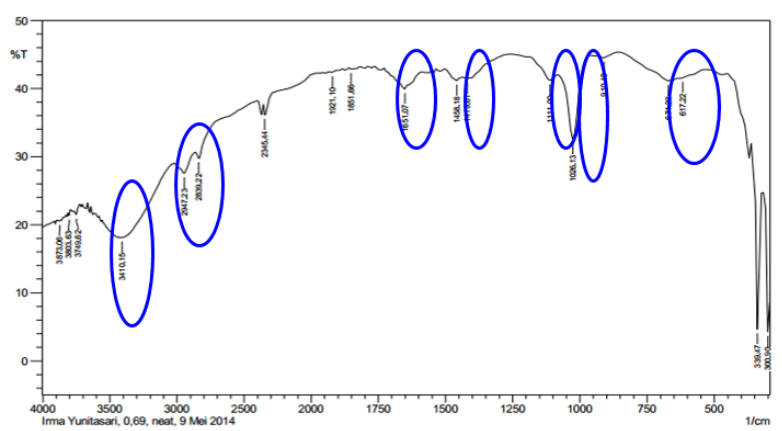

Gambar 3. Spektogram FTIR isolat A fraksi C ekstrak bunga Rosella.

\section{Karakterisasi isolat $\mathrm{B}(\mathrm{Rf} 0,76)$}

Berdasarkan data spektrofotometer UV-Vis isolat A memiliki dua pita serapan yaitu pada $331 \mathrm{~nm}$ (pita I) dan 277 (Pita II). Menurut Markham [11], senyawa yang memiliki pola pita tersebut digolongkan sebagai senyawa flavon. Pergeseran yang terjadi dan penafsirannya ditunjukan pada Tabel 5 .

Tabel 5: Penafsiran pereaksi geser isolat B

\begin{tabular}{|c|c|c|c|c|c|}
\hline \multirow{2}{*}{ Pelarut } & \multicolumn{2}{|c|}{$\lambda_{\max }(\mathrm{nm})$} & \multicolumn{2}{|c|}{$\begin{array}{l}\text { Pergeseran } \\
\text { (nm) }\end{array}$} & \multirow{2}{*}{ Penafsiran } \\
\hline & $\begin{array}{l}\text { Pita } \\
\text { I }\end{array}$ & $\begin{array}{l}\text { Pita } \\
\text { II }\end{array}$ & $\begin{array}{c}\text { Pita } \\
\text { I }\end{array}$ & $\begin{array}{c}\text { Pita } \\
\text { II }\end{array}$ & \\
\hline $\mathrm{MeOH}$ & 331 & 277 & - & - & \\
\hline $\mathrm{NaOH}$ & 380 & - & 49 & - & $4 \mathrm{OH}$ \\
\hline $\mathrm{NaOH} 5^{\prime}$ & 385 & 249 & 54 & 1 & \\
\hline $\mathrm{NaOAC}$ & 382 & 285 & 49 & 8 & $7-\mathrm{OH}$ \\
\hline $\mathrm{NaOAC} / \mathrm{H}_{3} \mathrm{BO}_{3}$ & 381 & 287 & 50 & 10 & $\begin{array}{l}\text { o-dihidroksi } \\
\text { pada cincin B }\end{array}$ \\
\hline $\mathrm{AlCl}_{3}$ & 375 & 290 & 44 & - & $5-\mathrm{OH}$ \\
\hline $\mathrm{AlCl}_{3} / \mathrm{HCl}$ & 361 & 266 & 38 & 1 & $\begin{array}{l}\text { o-dihidroksi } \\
\text { pada cincin B }\end{array}$ \\
\hline
\end{tabular}

Berdasarkan data hasil analisis spektrofotometer $U V$-Vis dengan menggunakan pereaksi geser diduga senyawa flavonoid dari isolat B bunga rosella adalah $5,7,3^{\prime}, 4^{\prime}$ '-tetrahidroksiflavon.

Karakterisasi menggunakan FTIR isolat B menunjukan gugus $-\mathrm{OH}$ $\left(3349,34 \mathrm{~cm}^{-1}\right), \mathrm{C}-\mathrm{H}$ alifatik $\left(2946,73 \mathrm{~cm}^{-1} ; 2834,61 \mathrm{~cm}^{-}\right.$ $\left.{ }^{1}\right), \mathrm{C}=\mathrm{O}\left(1657,92 \mathrm{~cm}^{-1}\right), \mathrm{C}=\mathrm{C}\left(1450,28 \mathrm{~cm}^{-1}\right), \mathrm{C}-\mathrm{H}$ tekuk $\left(1450,28 \mathrm{~cm}^{-1}\right), \mathrm{C}-\mathrm{O}-\mathrm{C}\left(1113,65 \mathrm{~cm}^{-1}\right), \mathrm{C}-\mathrm{O}\left(1024,36 \mathrm{~cm}^{-}\right.$ $\left.{ }^{1}\right)$, dan benzen tersubstitusi $\left(678,73 \mathrm{~cm}^{-1}\right)$. Spektra FTIR isolat $\mathrm{B}$ ditunjukan pada gambar 4 .

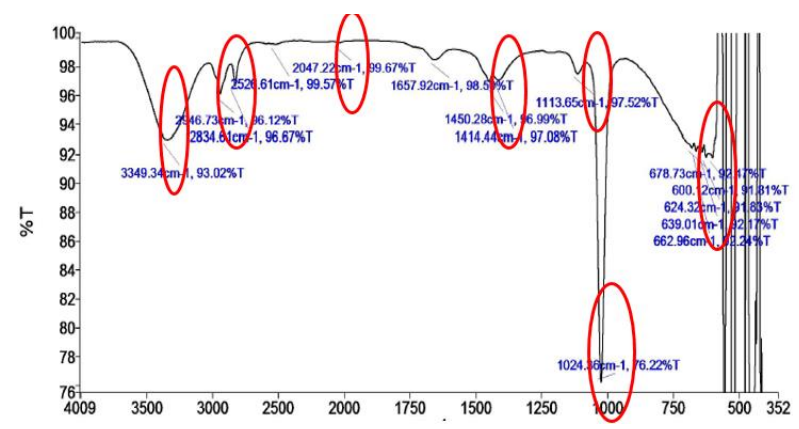

Gambar 4. Spektogram FTIR isolat B fraksi C ekstrak bunga Rosella 


\section{Kesimpulan}

Semua fraksi mampu menginhibisi $\alpha$-glukosidase, tetapi fraksi $\mathrm{C}$ memiliki aktivitas paling besar yaitu sebesar 31,163\% pada konsentrasi 1000 ppm. Dalam fraksi $\mathrm{C}$ terdapat 7 komponen senyawa, dan 2 senyawa yang diidentifikasi adalah isolat A yang diduga sebagai senyawa 3,3',4' -trihidroksilflavon dengan kadar relatif $23,33 \%$ dan isolat B diduga sebagai senyawa 5,7,3',4'tetrahidroksilflavon dengan kadar relatif $24,52 \%$.

\section{Daftar Pustaka}

[1] Tutik Siswanti, Okid Parama Astirin, Tetri Widiyani, Pengaruh ekstrak temu putih (Curcuma zedoaria Rosc.) terhadap spermatogenesis dan kualitas spermatozoa mencit (Mus musculus L.), BioSMART, $8,1,(2003) 38-42$

[2] Ika Pratiwi Khosimah Adinata, Khairul Anam, Dewi Kusrini, Identifikasi Senyawa Metabolit Sekunder Fraksi Aktif Daun Jarak Pagar (Jatropha curcas L.) dan Uji Aktivitas Larvasida terhadap Larva Nyamuk Aedes aegypti, Jurnal Kimia Sains dan Aplikasi, 16, 2, (2013) 42-45

[3] D Wynne Griffiths, Gwyn Moseley, The effect of diets containing field beans of high or low polyphenolic content on the activity of digestive enzymes in the intestines of rats, Journal of the Science of Food and Agriculture, 31, 3, (1980) 255-259

[4] Sawarni Mardiah, Reki W Ashadi, Arifah Rahayu, Budidaya dan Pengolahan Rosela Si Merah Segudang Manfaat, Agromedia Pustaka. Jakarta, 23, (2009)

[5] D Dahiru, OJ Obi, H Umaru, Effect of Hibiscus sabdariffa calyx extract on carbon tetrachloride induced liver damage, Biokemistri, 15, 1, (2003) 2733

[6] Ilul Urifah, (In Vitro) Inhibition of $\alpha$-Amylase, $\alpha$ Glucosidase and Lipase by Roselle (Hibiscus Sabdariffa) Extracts by In Vitro Method, Tehnologi Pertanian, Institu Pertanian Bogor, Bogor

[7] Adedayo O Ademiluyi, Ganiyu Oboh, Aqueous extracts of Roselle (Hibiscus sabdariffa Linn.) varieties inhibit $\alpha$-amylase and $\alpha$-glucosidase activities in vitro, Journal of medicinal food, 16, 1, (2013) 88-93

[8] Tangking Widarsa, Gede Wiranatha, Pemberian Ekstrak Methanol Daun Paliasa Menurunkan Kadar Glukosa Darah Tikus Hiperglikemik (METHANOL EXTRACT OF PALIASA LEAVES DECREASES BLOOD GLUCOSE LEVEL HYPERGLYCEMIC RATS), Jurnal Veteriner, 14, 4, 495-500

[9] Rudi Setiawan, Pengaruh pemberian ekstrak kelopak bunga rosela (hibiscus sabdariffa l) terhadap penurunan kadar gula darah tikus putih (rattus norvegicus) yang diinduksi aloksan, Biologi, Universitas Sebelas Maret, Solo

[10] Norman R. Farnsworth, Biological and phytochemical screening of plants, Journal of Pharmaceutical Sciences, 55, 3, (1966) 225-276 http://dx.doi.org/10.1002/jps.2600550302

[11] KR Markham, Cara Mengidentifikasi Flavonoid, ITB, Bandung, 1988.
[12] Suhad S Humadi, Viorica Istudor, Quantitative analysis of bio-active compound in Hibiscus sabdariffa L. extracts. Note I Quantitative analysis of flavonoids, in, Farmacia, 2008.

[13] Tina Rostinawati, Aktivitas Antibakteri Ekstrak Etanol Bunga Rosella (Hibiscus sabdariffa L.) terhadap Escherichia coli, Salmonella typhi dan Staphylococcus aureus dengan Metode Difusi Agar, Universitas Padjajaran, Bandung

[14] Reuben Alexander Day, Arthur Louis Underwood, Analisa Kimia Kuantitatif, Erlangga, 1994.

[15] AV Kristanti, NS Aminah, M Tanjung, B Kurniadi, Buku Ajar Fitokimia. Laboratorium Kimia Organik Fakultas Matematika dan Ilmu Pengetahuan Alam Universitas Airlangga, in, Airlangga University Press, Surabaya, 2008.

[16] Sri Sugiwati, Siswati Setiasih, Efy Afifah, Antihyperglycemic Activity of the Mahkota Dewa Leaf Extracts as an Alpha-Glucosidase Inhibitor, Makara Journal of Health Research, (2010) 74-78

[17] Adolfo Andrade-Cetto, Jaime Becerra-Jiménez, René Cárdenas-Vázquez, Alfa-glucosidaseinhibiting activity of some Mexican plants used in the treatment of type 2 diabetes, Journal of Ethnopharmacology, 116, 1, (2008) 27-32 http://dx.doi.org/10.1016/j.jep.2007.10.031

[18] Jeffrey Barry Harborne, Metode fitokimia, Padmawinata K, S. I, Institut Teknologi Bandung, Bandung, 1987. 